\title{
Vapaa sivistystyö tulevaisuuden kynnyksellä
}

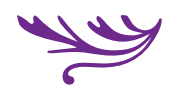

MaAilman tAlOUden tasapainottomuus, katastrofaaliset heilahtelut ja ihmisten liikkuvuus tekevät koulutustarpeiden ennustettavuuden vaikeaksi. Osin näistä syistä, osin yhteiskunnan rakennemuutoksesta johtuvista syistä koko suomalainen koulutuskenttä on turbulenssissa. Tästä saa osansa myös vapaan sivistystyön kenttä.

Vapaa sivistystyö on aina nojannut tiedon ja taidon kartuttamisen itseisarvoon. Ihminen on utelias uudelle, halukas uuden oppimiselle. Meihin suomalaisiin on juurrutettu usko perusoikeudesta sivistykseen.

Onko tästä perusoikeudesta rahoitusmalleineen tullut liiaksi itsestäänselvyys? Onko koulutusjärjestelmäämme luotu automaatti, jossa tarjonta on kasvanut yli kysynnän? Kilpailemmeko keskenämme toinen toisemme hengiltä? Nojaammeko liiaksi perinteisiin ja uskomme niiden kantavan myös tulevaisuudessa?

Opetus- ja kulttuuriministeriö (OKM) on asettanut tavoitteeksi vapaan sivistystyön oppilaitosmuotojen rakenteellisen uudistamisen. Uudistamista ryhdyttiin toteuttamaan oppilaitosten ylläpitolupien tarkastamisella. Kansalaisopistojen ylläpitoluvat uusittiin täysimääräisinä, osalle kansanopistoja lankesi määräaikainen ylläpitolupa. Nyt on rahoituslain uudistamisen vuoro.

\section{KANSALAISOPISTOJEN TILANNE}

Kansalaisopistokenttä on viimeisen kymmenen vuoden aikana kokenut uusjaon Paras-lain myötä. Kuntia on yhdistetty, ja kansalaisopistoista on muodostettu usean kunnan seutuopistoja.

Opistojen lukumäärä on lähes puoliintunut, mutta uskoakseni tarjonnan laatu ja tehokkuus on kasvanut. Voimavaroja yhdistämällä asiantuntemus on saatu laajempaan käyttöön. Suurinta osaa opistoista ylläpitää kunta.

Toki kunnat satoine lakisääteisine velvoitteineen ovat taloudellisessa ahdingossa, mutta tuskin luopuvat asukaspalautteessa kirjastopalvelujen kanssa kärkisijoille pääsevästä kansalaisopistotoiminnasta. Tähän on syytä uskoa huolimatta siitä, että vapaa sivistystyö ei ole lakisääteinen kunnan peruspalvelu.

\section{KANSANOPISTOJEN TILANNE}

Kansanopistot perusoppijaksoineen muodostavat nivelvaiheen koulutusverkoston väylänä lukiosta korkeakouluopintoihin. Vapaalla sivistystyöllä on siis kansanopistokoulutuksessa leimallisesti ammatillissivistävä tehtävä.

Ajoiko aika kansanopistojen koulutustehtävän ohi jo siinä vaiheessa, kun Suomen toisen asteen koulutusrakenne uudistettiin? Kansanopistoväki vannoo edelleen internaattipedagogiikan ja sosiaalipedagogiikan nimiin. Tällä vapaan sivistystyön koulutusmuodolla on viime vuosisadalla ollut tärkeä koulutuspoliittinen ja koulutuksellisen tasa-arvon edistäjän tehtävä erityisesti maaseudulla.

On pakko kysyä, ovatko maaseudulle sijoitetut suhteellisen suljetut internaattikampukset tämän päivän nuorille vetovoimainen vaihtoehto aikuisuuden ja ammatillisten opintojen kynnyksellä? Laskevat opiskelijamäärät eivät tue tätä väitettä. Katsooko kansanopistoväki liiaksi peruutuspeiliin vannoessaan edelleen internaattipedagogiikan nimiin?

\section{VAPAAN SIVISTYSTYÖN TULEVA ASIAKAS}

Isot kaupunkiopistot sekä maahanmuuttajakeskittymissä sijaitsevat kansalais- ja kansanopistot ovat 
KANSANOPISTOT VOISIVAT

TARJOTA ERINOMAISEN

SIIRTYMÄALUSTAN

TYÖELÄMÄSTÄ VAPAALLE.

ottaneet ja saaneet tärkeän uuden koulutustehtävän: maahanmuuttajakoulutuksen. Matalan kynnyksen lähipalveluna kansalaisopistot ovat tässäkin asiassa osoittaneet tarpeellisuutensa ja lunastaneet olemassaolonsa oikeuden.

Kokopäiväinen työvoimapoliittinen kotoutumiskoulutus sopii erinomaisesti myös maahanmuuttajakeskittymien kansanopistoille järjestettäväksi. Nuorisotakuun maahanmuuttajakoulutusta tarjotaan valtion taholta uudeksi merkittäväksi koulutustehtäväksi vapaalle sivistystyölle. Tämä on luontevaa edellä kuvatuilla paikkakunnilla, mutta maaseutuopistojen pelastajaksi tästä koulutustehtävästä ei ole.

Maahanmuuttajien kotoutumisen kannalta ei ole järkevää siirtää ja sulkea heitä maaseudun internaattiyhteisöihin. Tuloksellinen kotoutuminen voi tapahtua vain avoimessa yhteisössä tasavertaisena yhteiskunnan jäsenenä. Maahanmuuttajapaikkakunnilla sijaitsevat kansanopistot sopivat tähän tehtävään erinomaisesti tarjoten kotoutumisen tueksi yhteisöpedagogiikan osaamisensa.

Kansanopistojen perusoppijaksot tai niiden osat voivat toimia myös voimaannuttavina hengähdystaukoina työelämässä taukoa tarvitseville. Ovatko opistot epäonnistuneet markkinoinnissa, koska tätä vaihtoehtoa suhteellisen harvat aikuiset käyttävät? Vai, ovatko paikalliset kansalaisopistot kehittäneet koulutustarjontaansa niin, että sivistys- ja uuden oppimisen tarve tyydytetään oman kunnan lähipalveluna?

Lähivuosina eläköityy suuri määrä ihmisiä. Tämä ikäpolvi on varsin harjaantunut koulutuspalveluiden käyttäjä. Kansanopistot voisivat tarjota erinomaisen siirtymäalustan työelämästä vapaalle ja tarjota uuden elämänsisällön ja harrastuksen.

\section{UUDEN RAHOITUKSEN KYNNYKSELLÄ}

Vapaan sivistystyön jälkirahoitteisuus on muodostu- nut oppilaitosten sudenkuopaksi. Yksityisten säätiöiden, kannatusyhdistysten tai järjestöjen ylläpitämille opistoille nykyinen malli tarkoittaa venäläistä rulettia. Tulevan lukukauden toiminta joudutaan käynnistämään ilman tietoa rahoituksesta. Markkinat ovat arvaamattomat; mikä tänä vuonna oli huippusuosittua, saattaa seuraavana vuonna toteutua varsin pienellä opiskelijamäärällä tai jäädä vaille opiskelijoita.

Opettajien vakinaiset työsuhteet sekä infran ylläpitäminen pitävät kustannustason kuitenkin korkeana. Opiskelijamaksu- ja majoitustulot romahtavat. Lisäksi tämä kostautuu tulevien vuosien valtionapujen romahduksena.

Opiskelijamäärien väheneminen sekä rahoituksen ongelmat ovat ajaneet kansanopistot kehittämään toimintaansa ammatillisten kurssikeskusten tyyppisiksi. Lisäksi erilaisilla myyntikoulutuksilla, elämyspaketeilla ja täysihoitotarjonnalla yritetään hankkia hengenpitimiä. Kansanopistoista on muodostumassa koulutuksen sekatavarakauppoja, joissa valikoima on varsin kirjava, perustehtävä peräkamarissa.

Ehkä suurin haaste Suomen yhdeksällekymmenelle kansanopistolle ovat menneen vuosituhannen historiaa huokuvat rapistuneet ja aikansa eläneet kampukset. Hupenevat taloudelliset resurssit uppoavat seiniin, ja opetukseen riittää enää rippeet.

\section{KEHITYKSEN ESTEITÄ VAI RAJA-AITOJEN PURKUA?}

Ongelmaksi on muodostunut vapaan sivistystyön oppilaitosmuotojen eriytyminen kilpaileviksi saarekkeiksi.

Kansalaisopistot pitäytyvät toimimaan ylläpitäjäpaikkakunnilla ja keskinäistä kilpailua ei juurikaan esiinny. Kansanopistojen markkinointialue on seutukunta tai koko valtakunta. Keskinäinen kilpailu on kovaa.

Ovatko vapaan sivistystyön oppilaitokset rakkaita vihollisia vai toisiaan vierastavia serkuksia? Kuinka paljon, tai oikeasti kuinka vähän samalla paikkakunnalla tai seutukunnalla toimivat kansalaisopistot, kansanopistot, kesäyliopistot ja opintokeskukset tekevät yhteistyötä? Vapaan sivistystyön laki edellyttää yhteistyötä, mutta asetukset estävät sen. 
Yhtenä merkittävänä esteenä toimii rahoituslaki. Kansanopistot ovat sidottuja opiskelijaviikkopohjaiseen koulutustarjontaan. Lisäksi toimintaa säädellään ja rajoitetaan sitomalla se pääsääntöisesti ylläpitopaikkakunnalle. Tämä sotii jyrkästi nykyisen aikaan ja paikkaan sitomattoman koulutustarpeen kanssa.

Rahoituslain uudistamisen yhteydessä olisi välttämätöntä purkaa vapaan sivistystyön oppilaitosmuotojen raja-aidat. Rahoitus tulisi saattaa kaikille yksikköhinnaltaan samaksi. Tähän sopii mainiosti kansalaisopistojen ja kesäyliopistojen opetustuntiperustainen yksikkö. Kansanopistoissa valtakunnallisina oppilaitoksina voidaan jatkossakin järjestää internaattikoulutusta, jolloin näissä toteutettavaan opetukseen tulee saada internaattilisä. Ylläpitopaikkakuntaan sidottu normitus tulee purkaa. Näillä ratkaisuilla luodaan tehokkaita ja laadukkaita paikallisia ja seudullisia koulutusverkostoja, jotka pystyvät joustavasti ja nopeasti vastaamaan sivistystarpeen vaatimaan.

Rahoittajan eli ministeriön, ja viime kädessä eduskunnan, tulee myös selkeästi ratkaista oppilaitosten henkiinjäämisen reunaehdot. Kenttä odottaa lisäksi päättäjien arvovalintaa: onko Suomen koulutusjärjestelmässä tulevaisuudessa sijaa omaehtoiselle koulutukselle tai oikeammin sen tuelle vai onko vapaat sivistystyöt Suomessa tehty?

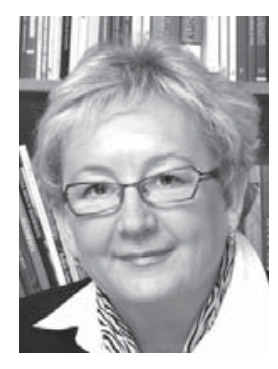

Kaisa Väyrynen

Oriveden Opiston reh Kansalaisopistojen lii varapuheenjohtaja 